\title{
Little Fire Ant Wasmannia auropunctata (Roger) (Insecta: Hymenoptera: Formicidae) ${ }^{1}$
}

\author{
Virginia Rose Seagal and Andrea Lucky²
}

The Featured Creatures collection provides in-depth profiles of insects, nematodes, arachnids and other organisms relevant to Florida. These profiles are intended for the use of interested laypersons with some knowledge of biology as well as academic audiences.

\section{Introduction}

The little fire ant, Wasmannia auropunctata (Roger), is a problematic invasive species from Central and South America that has become established in numerous countries and on islands around the world. This species has been documented in the state of Florida since at least 1924, where it was first recorded in Miami (Wetterer and Porter 2003). As the common name little fire ant (LFA) suggests, stings are painful, especially in relation to their small size (1.0-1.5 $\mathrm{mm}$ in length) (Figure 1). This species is also known as the electric ant in Australia.

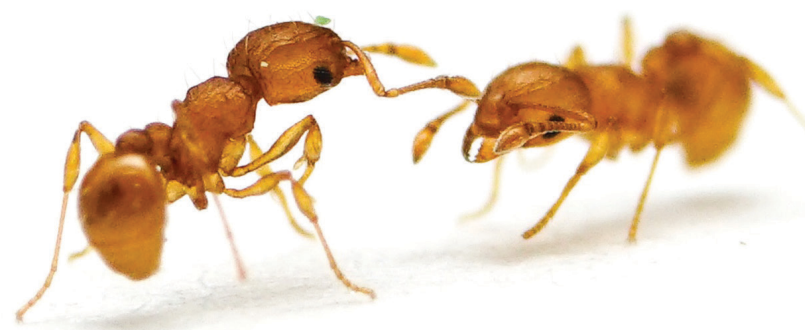

Figure 1. Workers of the little fire ant, Wasmannia auropunctata (Roger).

Credits: Virginia Rose Seagal, UF/IFAS
LFA is not closely related to the notorious red imported fire ant (RIFA) (Solenopsis invicta Buren); although both are in the subfamily Myrmicinae, they belong to different tribes (LFA: Attini, RIFA: Solenopsidini). Several characteristics contribute to LFA invasive success in new environments: generalist diet: ability to thrive in a variety of habitat types, supercolonial social structure, polygyny (multiple queens per colony), clonal reproduction in invasive populations, and association with human-modified habitats. This species has been unintentionally transported around the world as a direct result of movement of infested materials (Wetterer and Porter 2003).

\section{Synonymy}

AntCat and AntWiki provide the following synonyms for Wasmannia auropunctata:

\section{Obsolete combinations:}

Ochetomyrmex auropunctatum (Roger 1863)

Tetramorium auropunctatum (Roger 1863)

\section{Junior synonyms:}

Wasmannia atomum (Santschi, 1914)

\section{Obsolete combination(s):}

Xiphomyrmex atomum

Wasmannia atomum Wheeler, 1922

Wasmannia auropunctata australis Emery, 1894

1. This document is EENY-139 one of a series of the Entomology and Nematology Department, UF/IFAS Extension. Original publication date April 2021. Visit the EDIS website at https://edis.ifas.ufl.edu for the currently supported version of this publication. This document is also available on the Featured Creatures website at http://entomology.ifas.ufl.edu/creatures.

2. Virginia Rose Seagal; and Andrea Lucky; Entomology and Nematology Department, UF/IFAS Extension, Gainesville, FL 32611.

The Institute of Food and Agricultural Sciences (IFAS) is an Equal Opportunity Institution authorized to provide research, educational information and other services

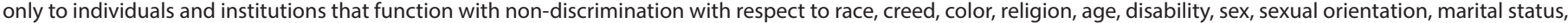
national origin, political opinions or affiliations. For more information on obtaining other UF/IFAS Extension publications, contact your county's UF/IFAS Extension office. U.S. Department of Agriculture, UF/IFAS Extension Service, University of Florida, IFAS, Florida A \& M University Cooperative Extension Program, and Boards of County Commissioners Cooperating. Andra Johnson, dean for UF/IFAS Extension. 
Wasmannia auropunctata laevifrons Emery, 1894

Wasmannia auropunctata nigricans Emery, 1906

Wasmannia auropunctata obscura Forel, 1912

Wasmannia auropunctata pulla Santschi, 1931

Wasmannia auropunctata rugosa (Forel, 1886)

\section{Obsolete combination(s):}

Ochetomyrmex auropunctatus rugosus

Wasmannia glabra Santschi, 1931

Wasmannia panamana (Enzmann, 1947)

\section{Obsolete combination(s):}

Hercynia panamana

Wasmannia sulcaticeps weiseri Forel, 1914

\section{Distribution}

The little fire ant is native to Central and South America, and has become established as an invasive species in tropical areas around the world (Foucaud et al. 2010). The non-native range of LFA (Figure 2) includes the Galapagos Islands, the Caribbean, West Africa (Gabon and Cameroon), Israel, Melanesia (New Caledonia, Solomon Islands, and Vanuatu), Polynesia (Wallis, Futuna, and Hawaii), Australia, Guam, Florida, and California (Wetterer and Porter 2003). In Florida, the extent of known established, overwintering colonies of Wasmannia auropunctata stretches from the Florida Keys (Monroe Co.) as far north as Gainesville (Alachua Co.) (Figure 3). LFA distribution is associated with human-modified habitat (Chifflet et al. 2018) and can be found along disturbed areas, such as highways and residential areas. The invasive range of this species is expected to continue to expand in tropical and subtropical regions as a result of transporting goods that are infested by this ant.

\section{Description}

Wasmannia belongs to the subfamily Myrmicinae, which can be distinguished from most other subfamilies by the two prominent "waist segments", the petiole and post-petiole (Bolton 2003). Adult LFA workers can be distinguished from those of other, similar genera by several distinctive features: pronounced frontal carinae (a pair of longitudinal ridges on the front of the head) that extend to the back of the head and form the prominent antennal scrobes (grooves along the side of the head) (Figure 4); a pair of spines located on the posterior segment of the middle part of the body (mesosoma) (Figure 5) (Wetterer and Porter 2003); and the convex mesosoma (middle part of the body) which lacks a mesonotal suture (narrow depression between the segments of the pro- and mesothorax) (Longino and
Fernandez 2007). Other identifying features of the genus Wasmannia include a characteristically thin portion of the anterior portion of the petiole (peduncle) that is noticeably extended and visible, and 11-segmented antennae with the last two enlarged into a club (Figure 5) (Fisher and Cover 2007).

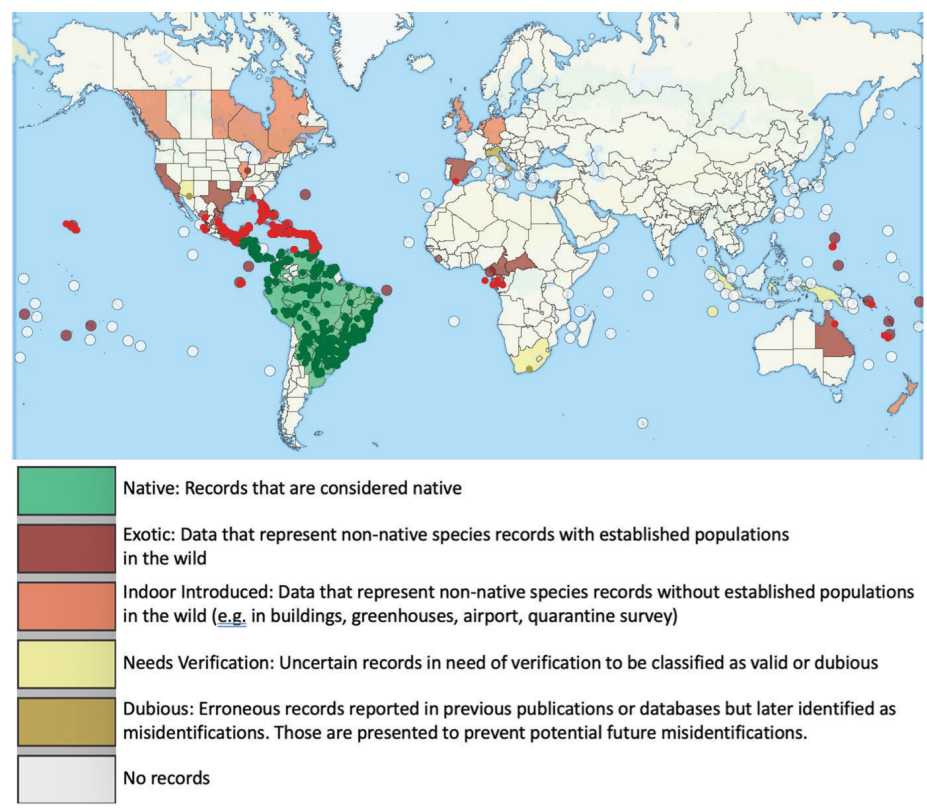

Figure 2. Map of global distribution of Wasmannia auropunctata provided by the Global Ant Biodiversity Informatics (GABI) project (accessed January 2021) (Guenard et al. 2017). Circles represent sampling sites.

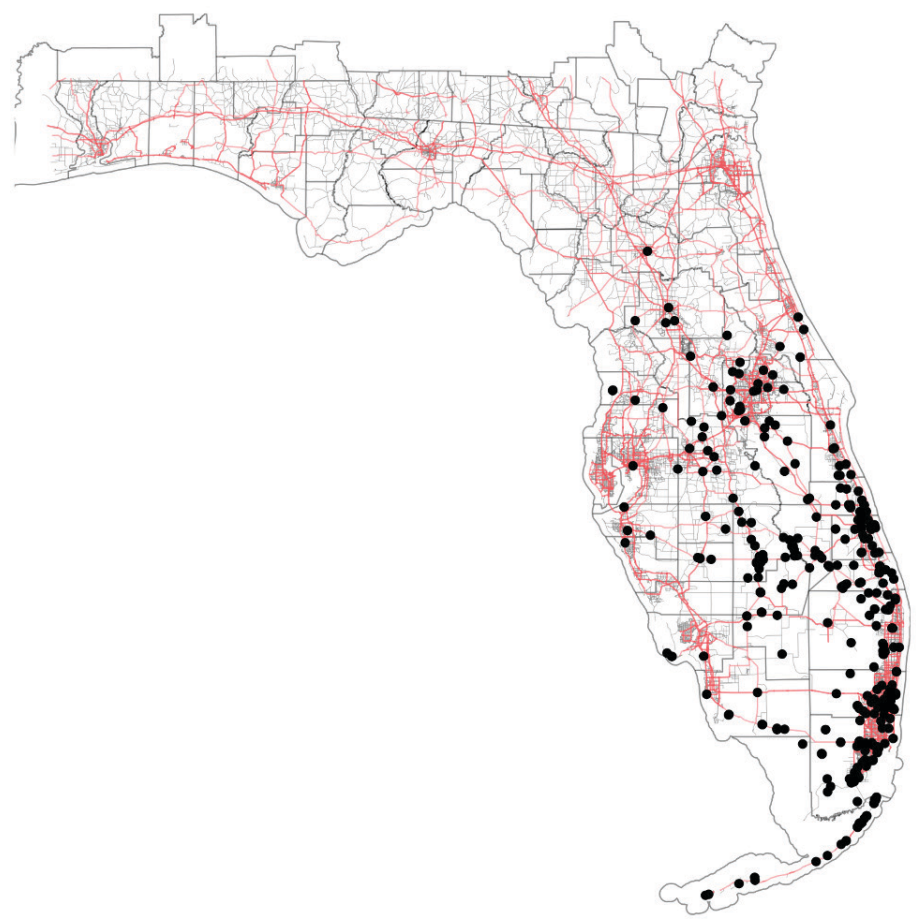

Figure 3. Map of Wasmannia auropunctata distribution in Florida. Black points represent localities where this species has been collected. Counties are outlined in black and red lines represent highways. Notice that most occurrences are often in disturbed landscapes such as along highways and in urbanized areas.

Credits: GPS coordinates provided by James Wetterer, Florida Atlantic University. Map by Virginia Rose Seagal, UF/IFAS 


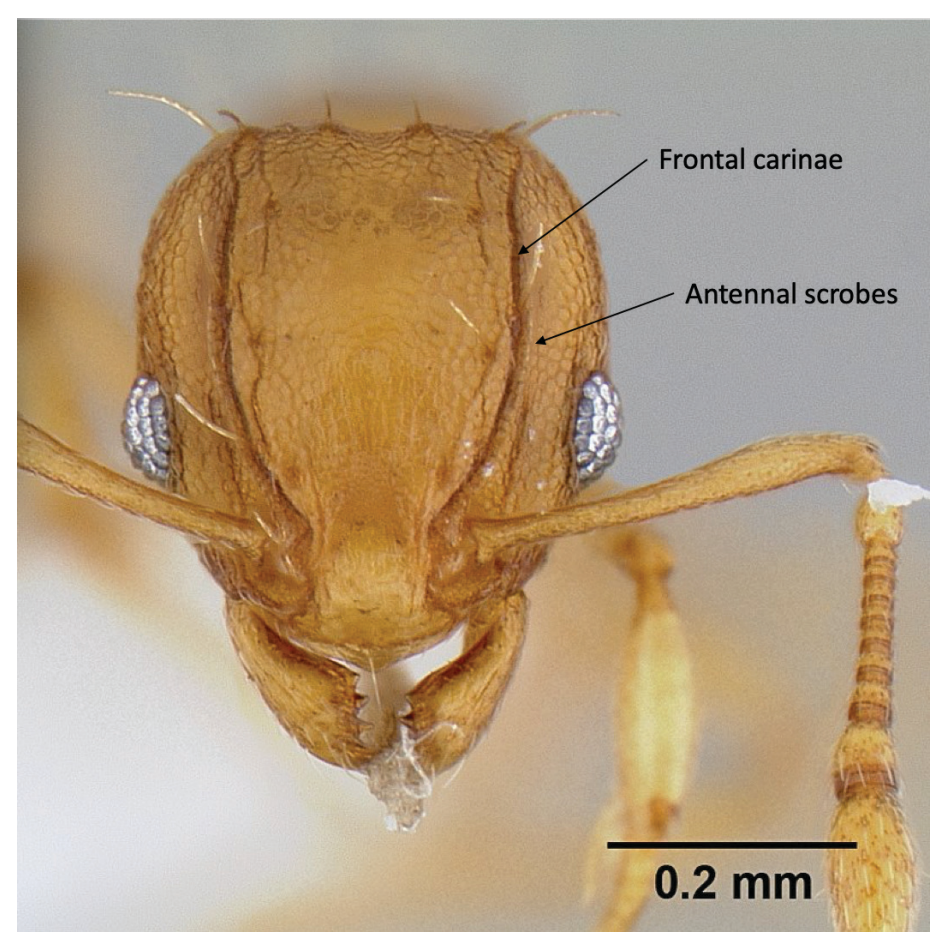

Figure 4. Anterior view of Wasmannia auropunctata (Roger) worker. Key characteristics of the genus are the frontal carinae (distinct ridge running longitudinally from the antennal insertion to the occiput of the head) and antennal scrobes (groove lateral to the frontal carinae that accommodates retracted antennae).

Credits: Michael Branstetter, California Academy of Sciences, from https://www.antweb.org/, CC License number CC-BY-SA-3.0

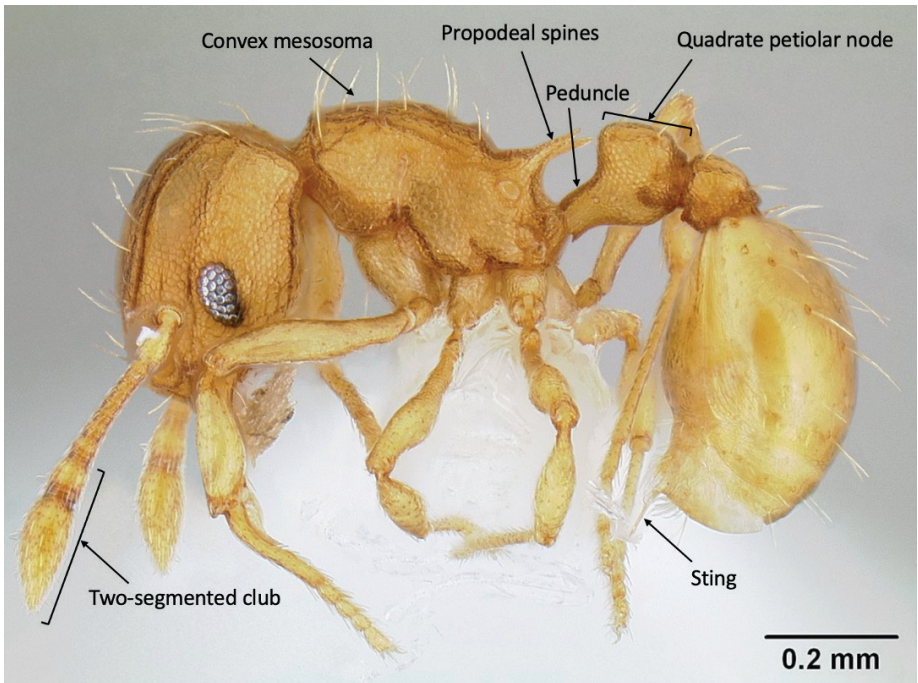

Figure 5. Lateral view of Wasmannia auropunctata (Roger) worker. The convex mesosoma without a mesonotal suture, length of the peduncle (equal to the length of the node), shape of the petiolar node (quadrate), and pair of propodeal spines are characteristic of this species.

Credits: Michael Branstetter, California Academy of Sciences, from https://www.antweb.org/, CC License number CC-BY-SA-3.0

LFA workers are small (1.0-1.5 $\mathrm{mm}$ in length), light brown to orange in color, and are generally slow moving. LFA workers can be differentiated from other species within the genus by their size, the narrow antennal scrobes, the distinctly square shape of the petiolar node (bump on the first waist segment) in lateral view, and the peduncle being similar in length to the node (Figures 4 and 5) (Longino and Fernandez 2007). In the invaded range this species forms supercolonies, so field diagnostic characters include the extremely high numbers of workers within a locality, often with many queens, and brood. LFA also have a surprisingly irritating and painful sting for such a small ant.

Queens are easily distinguished from workers by their larger size (approximately $4.5 \mathrm{~mm}$ in length compared to 1.0-1.5 mm workers) and darker, reddish-brown coloration (Figures 6 and 7) (Wetterer and Porter 2003). Queens have deep and distinct antennal scrobes, and their propodeal spines are equally as long as they are wide at the base. The head is broad, greater than $0.75 \mathrm{~mm}$ in width (Longino and Fernandez 2007). This species has the largest difference in size between workers and queens in the genus Wasmannia, which can be used as a distinguishing characteristic (Longino and Fernandez 2007). The presence of multiple queens among high density of workers can help diagnose this species.

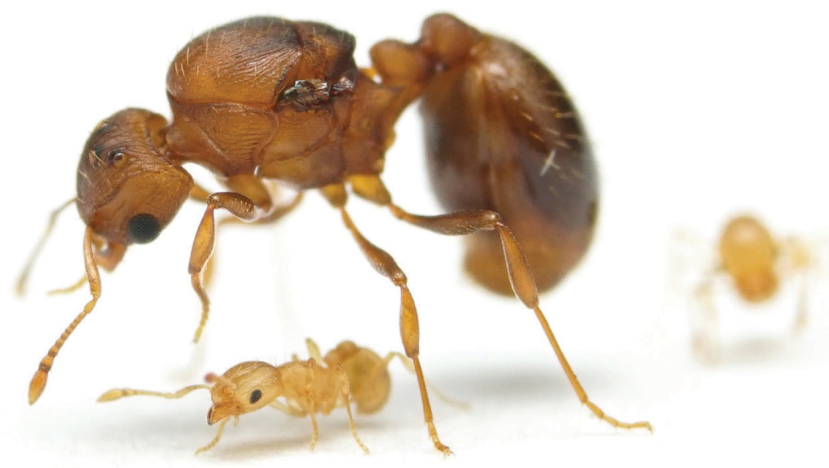

Figure 6. Wasmannia auropunctata (Roger) queen and workers. Note difference in size and coloration.

Credits: Virginia Rose Seagal, UF/IFAS

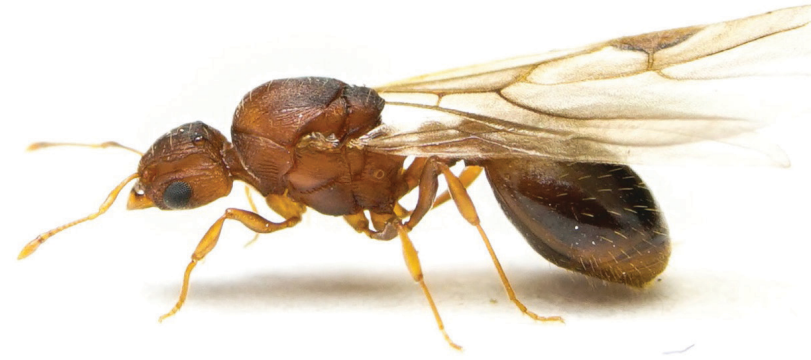

Figure 7. A Wasmannia auropunctata (Roger) alate queen.

Credits: Virginia Rose Seagal, UF/IFAS

LFA males are not as abundant as the other castes. Males are similar in color and length to queens and also have prominent ocelli and wings, but they have a unique set of other physical characteristics (Figure 8). The head is oval and slightly narrower than that of a queen, ranging from 5.5 to $6.2 \mathrm{~mm}$ in width, and the large compound eyes cover 
half of the head when viewed laterally (Cuezzo et al. 2015), There are many carinae (ridges on the head) that extend diagonally from the base of the mandibles to the front of the eyes, and antennae are 13-segmented with the last segment elongated and not enlarged into a club (Cuezzo et al. 2015). There is a quadrate petiolar node, however it is more pointed with less pronounced angles than that of workers. Males do not have a stinger but rather a subgenital plate that extends from the end of the abdomen.

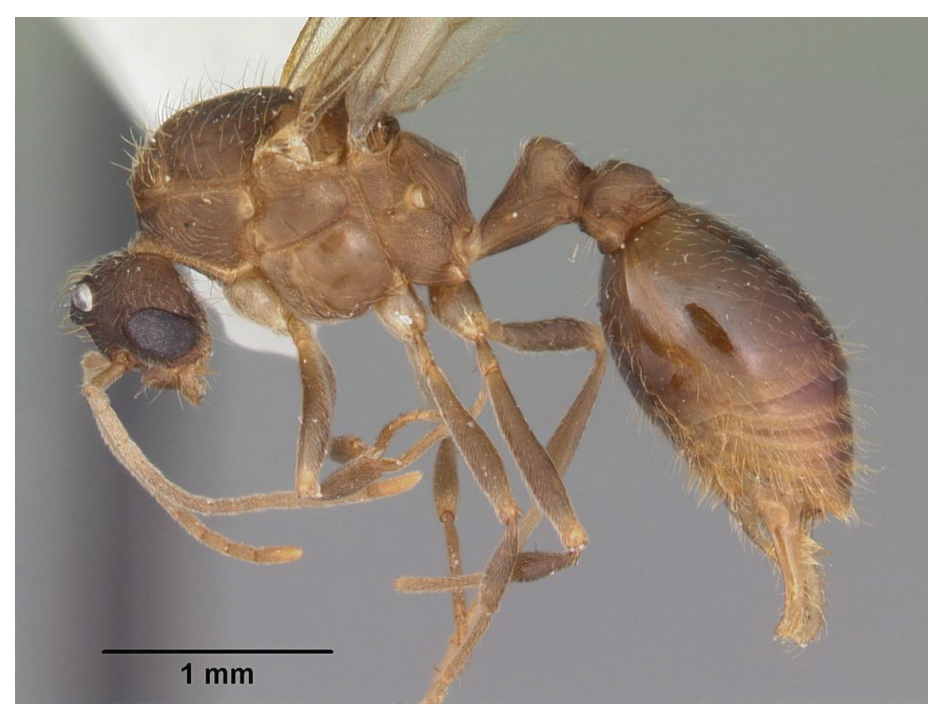

Figure 8. Wasmannia auropunctata (Roger) male.

Credits: April Nobile, California Academy of Sciences, from https:// www.antweb.org/, CC License number CC-BY-SA-3.0

\section{Biology}

Like all ants (family Formicidae), LFA is a eusocial species, in which all workers are sterile females, while all queens and males are reproductive. In the species' native range, colonies may display a monogynous social structure, with a single queen and a limited number of workers that display aggression to non-nestmates and defend territorial boundaries. In some parts of the native range, and throughout the non-native range, LFA are unicolonial. These populations have multiple queens and can grow to include many millions of workers, as they do not establish and defend territorial boundaries. Workers display no aggression to other members of these "supercolonies". Rapid colony growth is due to a high reproductive rate and the production of many winged reproductives (males and females), called alates. These ants do not fly, however, rather they remain close to their parental supercolony, reproducing and expanding its boundaries (Wetterer and Porter 2003).

LFA undergoes sexual reproduction in its native range, however some native and all invasive populations of this species have a surprising clonal reproductive system, in which the queens and males are produced clonally and the sterile workers are produced sexually (Fournier et al. 2005). Separate lineages of queens and males in clonally reproductive colonies results in higher genetic variation, which may allow these populations to more easily adapt to newly invaded environments. This method of clonal reproduction describes 98 percent of LFA populations in invaded ranges, but only accounts for two thirds of sampled colonies in native ranges (Foucaud et al. 2010).

Clonal queens. Reproductive females are produced clonally through a process called ameiotic parthenogenesis, in which only mitosis (not meiosis) occurs. In this process unfertilized eggs are laid by a queen which passes on an identical set of maternal genes to each daughter queen. Each queen can in turn pass along the same genetic material to subsequent generations of queens, creating clonal lineages that do not include new genetic material from males (Fournier et al. 2005).

Clonal males. Males are produced as a result of fertilized eggs laid by a queen, but all maternal genes are eliminated. The genetic lineage of males is therefore exclusively based on paternal genetic material (Fournier et al. 2005).

Sexually produced workers. While parallel clonal processes maintain separate genetic lineages of reproductive females and males in clonally reproducing colonies, the sterile workers in these colonies are the product of typical sexual reproduction. This reproductive strategy results in workers having significantly higher heterozygosity (more genetic variability) than those in sexually reproducing populations in the native range. Higher heterozygosity of workers in clonally reproductive populations may benefit LFA in adapting to various conditions and obstacles in non-native regions (Foucaud et al. 2010).

LFA is associated with human-modified habitats, and clonal reproduction in combination with an affinity for disturbed environments aid the expansion of this species in its native range in Argentina (Chifflet et al. 2018) and contribute to its spread worldwide. Clonal reproduction contributes to LFA's competitive dominance as an invasive species. These populations are not limited by competition with neighboring colonies. They can reproduce rapidly and achieve high worker populations.

Nesting behavior also contributes to LFA's invasive success. This species exhibits polydomy, in which no central nest is established and instead the population is diffuse, with many nests spread across the occupied area. Individuals move freely among the nests. LFA do not build their nests deep underground, but instead occupy a variety of natural and 
human-made cavities close to the ground surface (Wetterer and Porter 2003). Some examples of nesting sites include spaces under rocks, within logs, inside plant material or compost, in hay bales, and under leaf litter (Figure 9).

\section{Economic Importance}

Wasmannia auropunctata is considered an agricultural pest partly due to its painful sting, which can make work in infested fields miserable. In addition to foraging on the ground, LFA also forage arboreally (in trees) and can fall from branches and leaves onto agricultural workers and animals, stinging as they get trapped against the skin. Stings to the eyes can cause corneal lesions in humans, livestock, and domestic pets (Rosselli and Wetterer 2017). Domestic and wild animals can become blinded and their lifespan shortened due to large numbers of LFA stinging the eyes and face (Rosselli and Wetterer 2017).

LFA can also facilitate damage to agricultural crops through mutualistic interactions with honeydew-producing insects, which feed on the sap of plants and are themselves serious pests. In Brazil, the presence of Wasmannia auropunctata was associated with a significant increase in mealy bugs, which are damaging to crops and can spread plant diseases (de Souza et al. 1998). In the 1970s Wasmannia auropunctata was intentially introduced to the Solomon Islands as a biological control agent to prey on the nut-fall bug (Amblypelta sp.) (Wetterer 2009). However, this introduction turned disastrous because, in addition to becoming a serious stinging pest of farm workers and livestock, this ant species facilitated an increase in sapsucking plant pests such as scales, aphids, and mealybugs, leading to losses in crop yields (Fasi et al. 2012). Damage caused by these pest insects can be dramatically increased by the presence of ants, which protect the pests from predators and can distribute them to new plants. By tending the sapsucking insects, which excrete a carbohydrate-rich honeydew, the ants gain an abundant and consistent nutritional food source (Fasi et al. 2012).

\section{Ecological Importance}

The presence of invasive ants can dramatically decrease native biodiversity and negatively impact entire ecosystems (Bertelsmeier, Blight, and Courchamp 2016). A study conducted in New Caledonia found that the invasive population of LFA completely decimated local ant diversity and abundance, making up to 96 percent of the postinvasion ant biomass (Le Breton et al. 2003). In this area, LFA outcompeted native ants for food resources as well as occupied a wide variety of nesting sites underexploited by native fauna. In Israel, LFA presence also negatively impacts ant abundance, species richness, and community composition. High densities of LFA in this region were found to be correlated with a decrease in other ant species abundance and species richness, as well as the abundances of beetles and spiders (Vonshak et al. 2010).

This pattern of biodiversity loss can be seen in many of the places Wasmannia auropunctata has become established. For example, on Santa Cruz Island in the Galapagos, this species has also reduced the abundance of native ants causing many species to become endangered (Clark et al. 1982). Throughout the Galapagos Islands LFAis impacting a variety of arthropods, causing the decline in abundance of flying insects and multiple species of arachnid (Lubin 1984), as well as other native wildlife including reptiles and birds. LFA has been shown to have devastating effects on ecosystems it invades, making its presence a big concern to local biodiversity. In Hawaii, the distribution of this invasive ant is extensive, reaching over 4000 locations across the big island of Hawaii (Lee et al. 2015). Here LFA's sting negatively impacts the survival of endangered reptiles and birds, harms domestic pets, and effects humans by nesting within and around man-made structures, including inside homes.

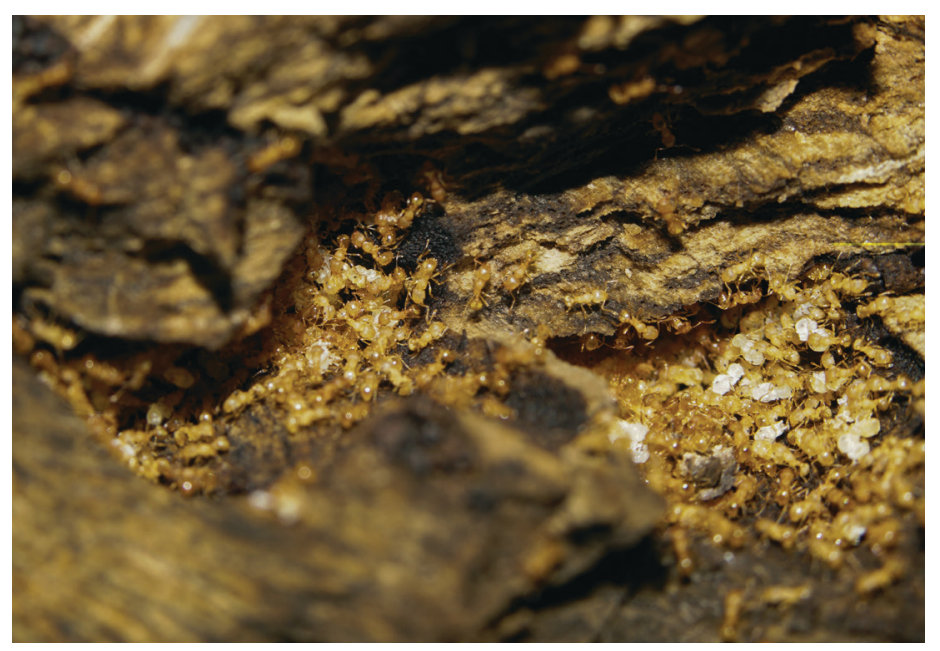

Figure 9. A fragment of a Wasmannia auropunctata (Roger) colony nesting within dead wood. Pale pupae can be seen among the yellow workers.

Credits: Virginia Rose Seagal, UF/IFAS

\section{Management}

Humans are responsible for the spread of Wasmannia auropunctata around the world. This species is introduced to new localities primarily through transportation of infested plants, plant material, and soil (Krushelnycky et al. 2005). The most effective way to prevent further spread is to inspect plant material before transport to ensure no ants inhabit any part of the plant, soil, or packing material. The 
second most effective prevention strategy is to prevent arriving species from becoming established by inspecting and monitoring around shipping ports and transportation hubs. Containment and elimination of populations when they are small and isolated offers the possibility of eradication of individual populations. Once established populations are large and expansive, eradication is unliklely (Krushelnycky et al. 2005).

Chemical control using insecticide baits is thought to be most effective for managing small, isolated populations, while control of larger populations is a challenge and the subject of ongoing research. Attempts to control and eradicate LFA have been made in multiple invaded areas around the world. Researchers have tested the effects of various pesticides on populations on the island of Hawaii, where temporary suppression of LFA populations was achieved with baiting (Souza et al. 2008). However, 100\% reduction is very difficult given the ability for this species to reach such high densities in its invaded regions. LFA was successfully eradicated in Maui, Hawaii, but only after application of a combination of three insecticides, incuding an indoxacarb treatment (Vanderwoude et al. 2010). In the Galapagos an alternative pesticide treatment was applied but ultimately had no effect on the invasive LFA populations (Ulloa-Chacon and Cherix 1993). Despite previous failed efforts, LFA has since been eradicated on islands in the Galapagos. Eradication was achieved on Santa Fe Island after repeated cutting and burning of vegetation in addition to application of four insecticides (Wetterer and Porter 2003). On Marchena Island LFA was successfully eradicated by thoroughly treating the area with chemicals over the course of two years (Causton, Sevilla, and Porter 2005).

Eradication of invasive pests such as LFA can be very economically costly and damaging to the environment. Prevention and early detection are the most effective ways to avoid negative impacts caused by this invasive species. Suspected infestations of LFA should be brought to the attention of specialists to confirm their identification and to implement appropriate control measures.

\section{Selected References}

Bertelsmeier C, Blight O, Courchamp F. 2016. Invasions of ants (Hymenoptera: Formicidae) in light of global climate change. Myrmecological News 22: 25-42.

Bolton B. Wasmannia auropunctata (Roger, 1863) valid. AntCat: An Online Catalog of the Ants of the World, https://antcat.org/ (12 January 2021).
Bolton B. 2013. Synopsis and classification of Formicidae. Memoirs of the American Entomological Institute 71: $1-370$.

Causton CE, Sevilla CR, Porter SD. 2005. Eradication of the little fire ant, Wasmannia auropunctata (Hymenoptera: Formicidae), from Marchena Island, Galapagos: on the edge of success? Florida Entomologist 88: 159-169.

Chifflet L, Guzman NV, Rey O, Confalonieri VA, Calcaterra LA, Chaline N. 2018. Southern expansion of the invasive ant Wasmannia auropunctata within its native range and its relation with clonality and human activity. PLOS ONE 13: e0206602.

Clark DB, Guayasamin C, Pazmino O, Donoso C, Paez de Villacis Y. 1982. The tramp ant Wasmannia auropunctata: Autecology and effects on ant diversity and distribution on Santa Cruz Island, Galapagos. Biotropica 14: 196-207.

Cuezzo FDC, Calcaterra L, Chifflet L, Follet P. 2015. Wasmannia Forel (Hymenoptera: Formicidae: Myrmicinae) in Argentina: Systematics and distribution. Sociobiology 62: 246-265.

de Souza ALB, Delabie JHC, Fowler HG. 1998. Wasmannia spp. (Hym., Formicidae) and insect damages to cocoa in Brazilian farms. Journal of Applied Entomology 122: 339-341.

Fasi J, Brodie G, Vanderoude C. 2012. Increases in crop pests caused by Wasmannia auropunctata in Solomon Islands subsistence gardens. Journal of Applied Entomology 137: 580-588.

Fisher BL, Cover SP. 2007. Ants of North America: A guide to the genera. University of California Press.

Foucaud J, Orivel J, Loiseau A, Delabie JHC, Jourdan H, Konghouleux D, Vonshak M, Tindo M, Mercier JL, Fresneau D, Mikissa JB, McGlynn T, Mikheyev AS, Oettler J, Estoup A. 2010. Worldwide invasion by the little fire ant: Routes of introduction and eco-evolutionary pathways. Evolutionary Applications 1752-4571: 363-374.

Fournier D, Estoup A, Orivel J, Foucaud J, Jourdan H, Le Breton J, Keller L. 2005. Clonal reproduction by males and females in the little fire ant. Nature 435: 1230-1234.

Guenard B, Weiser M, Gomez K, Narula N, Evonomo EP. 2017. The Global Ant Biodiversity Informatics (GABI) Database: Synthesizing Data on the Geographic Distribution 
of Ant Species (Hymenoptera: Formicidae). Myrmecological News 24: 83-89.

Krushelnycky PD, Loope LL, Reimer NJ. 2005. The ecology, policy, and management of ants in Hawaii. Proceedings of the Hawaiian Entomological Society 37: 1-25.

Le Breton J, Chazeau J, Jourdan H. 2003. Immediate impacts of invasion by Wasmannia auropunctata (Hymenoptera: Formicidae) on native litter ant fauna in a New Caledonian rainforest. Austral Ecology 28: 204-209.

Le Breton J, Delabie JHC, Chazeau J, Dejean A, Jourdan H. 2004. Experimental evidence of large-scale unicoloniality in the tramp ant Wasmannia auropunctata (Roger). Journal of Insect Behavior 17: 263-271.

Le Breton J, Jourdan H, Chazeau J, Orivel J, Dejean A. 2005. Niche opportunity and ant invasion: The case of Wasmannia auropunctata in a New Caledonian rain forest. Journal of Tropical Ecology 21: 93-98.

Lee DJ, Motoki M, Vanderwoude C, Nakamoto ST, Leung P. 2015. Taking the sting out of Little Fire Ant in Hawaii. Ecological Economics 111: 100-110.

Longino JT, Fernandez F. 2007. Taxonomic review of the genus Wasmannia. Memoirs of the American Entomological Institute 80: 271-289.

Lubin YD. 1984. Changes in the native fauna of the Galapagos Islands, following invasion by the little red fire ant, Wasmannia auropunctata. Biological Journal of the Linnean Society 21: 229-242.

Rosselli D, Wetterer JK, 2017. Stings of the ant Wasmannia auropunctata (Hymenoptera: Formicidae) as cause of punctate corneal lesions in humans and other animals. Journal of Medical Entomology 54:1783-1785.

Souza E, Follett PA, Price DK, Stacy EA. 2008. Field suppression of the invasive ant Wasmannia auropunctata (Hymenoptera: Formicidae) in a tropical fruit orchard in Hawaii. Journal of Economic Entomology 101:1068-1974.

Stanley MC. 2004. Review of efficacy of baits used for ant control and eradication. Landcare Research Contract Report: LC0405/044.
Vanderwoude C, Onuma K, Reimer N. 2010. Eradicating Wasmannia auropunctata (Hymenoptera: Formicidae) from Maui, Hawaii: The use of combination treatments to control an arboreal invasive ant. Hawaiian Entomological Society 42: 23-31.

Vonshak M, Dayan T, Ionescu-Hirsh A, Freidberg A, Hefetz A. 2010. The little fire ant Wasmannia auropunctata: a new invasive species in the Middle East and its impact on the local arthropod fauna. Biological Invasions 12: 1825-1837.

Wetterer JK. 2009. Species profile: Wasmannia auropunctata. Global Invasive Species Database, http://www. iucngisd.org/gisd/ (13 January 2021).

Wetterer JK, Porter SD. 2003. The little fire ant, Wasmannia auropunctata: Distribution, impact and control. Sociobiology 41: 1-41. 